fungus itself or by its toxins. For my part I am most inclined to believe that the condition has an internal toxic origin. Jadassohn, in 1911, considered an exogenous inoculation as being the more probable. However no fungus is found in the lesions (only Guth has on one occasion found a single mycelial thread) which by their diffuse, indeed in some cases almost generalised exanthematic appearance, certainly point to some internal agent as being the cause of the affection. B. Bloch also supposes that the condition has an internal toxic origin.

(My two cases of Lichenoid trichophytides were demonstrated before the Danish Dermatological Society in November, 1915.)

I have, since the above was written, seen two more cases of very extensive trichophytides in children with kerion. In one of these (Figs. 3 and 4) there developed extremely numerous minute psoriasiform scales on the papules.

(NoTE.- Since this article was written I have obtained a culture of Trichophyton faviforme from a sister of Case 2, who also suffered from kerion and lichenoid trichophytides.)

TWO CASES OF HERPES ZOSTER ASSOCIATED WITH A GENERALISED ERUPTION OF VARICELLA-LIKE SPOTS: ONE OF THE CASES FOLLOWED BY OCULOMOTOR PARESIS, MYDRIASIS, AND FRONTAL AN ESTHESIA.

With a Short Analysis of the Literature of the Subject and Remarks on the Attology of Herpes Zoster.

By F. PARKES WEBER, M.D., F.R.C.P.

First Case.

THE patient, A. H-, Jewish, male, aged 59 years, was admitted to hospital on October 30th, 1915, suffering from chronic lymphatic leukæmia, with considerable enlargement of the cervical, axillary and inguinal lymphatic glands, and moderate enlargement of the spleen and liver. The glandular enlargement had commenced gradually some six years ago, and about one and a vot. XXrinI. 
half years ago the patient had suffered from malaria in Palestine. Roentgen-ray examination of the thorax (Dr. James Metcalfe) showed masses of enlarged lymphatic glands at each side of the great vessels above the heart and in the mediastinum. Blood-examination (November 1st, 1915) : hæmoglobin, 60 per cent. ; red cells 3,200,000 and white cells 53,600 to the c.mm. of blood. Of the white cells 97 per cent. were small lymphocytes. The red cells showed slight. poikilocytosis, polychromatophilia, and anisocytosis. No nucleated red cells were seen. 'The Wassermann reaction (Dr. Hans Schmidt) was negative. Treatment with arsacetin was commenced on November 6th, 1915, and two weeks later an eruption of typical Herpes zoster of the right shoulder broke out (connected doubtless with the arsenical therapy), which was accompanied by a good deal of pain. About five days later a generalised but scanty eruption of varicellalike spots occurred. These spots were scattered about the trunk, and gradually disappeared without causing any trouble, whereas the patches of the Herpes zoster proper dried up, leaving depressed scars covered with dark scabs. Early in December, however, the patient was apparently free from any pain connected with the Herpes zoster, though he complained of other pains lower down in the back.

The patient left the hospital on December 13th, 1915, and (in connection with the remarks I shall make further on) it is perhaps just worth mentioning (though doubtless a mere coincidence) that a little boy, aged 4 years, who was in the same ward with the patient, but was discharged on December 3rd, 1915, developed varicella, I was told, ten days later at his own home-that is to say, ten days after leaving my patient with Herpes zoster.

\section{Second Care.}

The patient was an elderly widow, about 60 years of age, who, during the last week of August and the first two weeks of September, 1915, suffered from neuralgia of the left side of the head in the occipital region and in the area of the distribution of the first branch of the fifth cranial nerve, particularly nasal and supra-orbital neuralgia. She likewise complained of slight general malaise. Then (September, 1915) an eruption of typical Herpes zoster appeared on the forehead, and this soon extended over the whole of the left 
half of the forehead, the left temple and front part of the hairy scalp to the middle line, involving also the upper eyelid, the left half of the nose, and the outer part of the margin of the left lower eyelid. The pain continued very severe. The herpetic eruption soon became confluent and partly hæmorrhagic. There was much œdema of the whole face, particularly of the left half. The pre-auricular lymphatic glands and those along the anterior border of the sternomastoid muscle were much enlarged and very tender. At the end of the first week of the typical Herpes zoster affection a generalised vesicular eruption of small varicella-like spots was noticed, scattered over the trunk and extremities; two spots were situated near the outer margin of the right orbit, about six were on the lower extremities, and about twenty were on the chest. This generalised vesicular eruption was not accompanied by any subjective symptoms, and the spots disappeared gradually in the course of two weeks. The true Herpes zoster eruption, on the other hand, took two months to dry up; by the end of that time the scabs had largely disappeared.

About six weeks after the onset of the Herpes zoster, when the patient began to keep her left eye open again, she complained of diplopia, and this, on examination, was found to be due to paresis of the left reotus superior muscle. The diplopia disappeared about three weeks later.

The eyeball was considerably injected throughout the illness and there was much lacrymation, with a good deal of muco-purulent discharge from the conjunctiva. The cornea, apart from some slight marginal erosions, remained free from ulceration and infiltration. Sensation in the cornea and bulb was distinctly impaired. The eye was kept under atropine.

The condition on December 10th, 1915, that is to say, about three months after the commencement of the illness, was as follows. There was very severe neuralgia in the left eye, the left temple and side of the head, and the left half of the forehead; also in the region of the orbital branch of the second division of the fifth nerve (that region was distinctly hypersensitive to touch). There was cutaneous anæsthesia (to touch and pressure) of the left half of the forehead and the upper eyelid. There was cutaneous hypo-æsthesia of the left front portion of the scalp up to the middle line. The upper eyelid was still red and somewhat thickened. There was moderate lacrymation. The 
pupil (two weeks after discontinuing the use of atropine) was still somewhat dilated and reacted sluggishly to light. There was still a little œdema of the left cheek. The eyeball was slightly injected, but there was hardly any excess of the conjunctival secretion. There was much scarring of the left half of the forehead. The conjunctival sensation was purposely not tested.

During the second week of January, 1916, the left pupil became normal again in regard both to its size and its reactions. To-day (Eebruary 18th, 1916) I hear that, except for the pupil, the condition is much the same as noted on December 10th, 1915. There is some chloasma-like pigmentation of the left cheek. The neuralgia and anæsthesia remain. A slight improvement followed treatment with eight intra-muscular injections of "liodine," but that course of treatment had to be discontinued on account of exacerbations of old chronic bronchitic troubles, with rise of temperature (up to $102^{\circ} \mathrm{F}$.), lasting for two days or so at a time. On one occasion a scarlatiniform eruption appeared on the patient's trunk and lasted about two days.

I am indebted for the notes of the second case to my colleague, Dr. Charles Markus, through whose kindness I saw the patient.

\section{ReMarKs.*}

The Generalised Eruption, and the Question of the Aftiology of Herpes Zoster.

Many cases of Herpes zoster associated with or followed by a generalised vesicular eruption have been described ( $c f$. references Nos. 1 to 20), mostly under the heading Herpes zoster generalisatus. Minet and Leclereq (14), who collected twenty.five cases, say that the generalised eruption may break out simultaneously with, or from a few hours to a few days after, the typical Herpes zoster. A case published by Fischl (19) was in a patient with lymphatic leukæmia; and lymphatic leukæmia was present likewise in the first case of the present paper. Several of the recorded cases of Herpes zoster generalisatus have been in elderly persons (for instance, references 6 , $13,15,17)$. In the recent account of a case of generalised Herpes

* The figures in brackets are the numbers of the references to the literature and notes at the end of the paper. 
zoster in a man, aged 80 years, G. Pernet (18) writes that in Herpes zoster " it is well known, since Tenneson (1) called attention to the point, that here and there aberrant vesicles may usually be found if carefully looked for, but in this case there were a very large number of discrete vesicles scattered all over the trunk and limbs, very few being found, however, below the knees. . . . There were also a few about the face and scalp, but none in the mouth. The generalised vesicular rash looked like a bad attack of varicella."

It has been suggested that Herpes zoster is a modified and localised form of varicella (21 to 29). This suggestion would explain likewise the occasional evidence of contagion in Herpes zoster (30 to 35 , and 22).

Johann von Bokay (21), at the 16th International Medical Congress, in 1909, published nine interesting observations. In 1888 he examined a child who developed typical varicella ten days after an eruption of thoracic Herpes zoster in another child in the same family. His eight other similar observations were made during the following twenty-one years, and in each of them typical varicella was observed to break out in a patient (in one instance an adult patient) eight to twenty days after exposure to typical Herpes zoster. In three of the observations the Herpes zoster was followed by respectively two, three, and four cases of varicella. In none of the cases was there any evidence of exposure to ordinary varicella.

Paul Heim (22) records a similar observation of his own. A mother suffered from typical thoracic Herpes zoster, and the only one of her children who was at home when the eruption broke out developed typical varicella ten days later. Four days after the commencement of the mother's eruption another of her children came home and developed typical varicella twelve days later-that is to say, six days after the first child. The varicella eruption was much more severe in the second child. In the right axillary region the vesicles were smaller than elsewhere and had a zoster-like grouping, and the child complained of pain there. J. von Bokay had also observed that general varicella eruptions may sometimes show local zoster-like grouping of the vesicles, and he had quoted confirmatory evidence from the writings of earlier authors. Heim suggests that the unknown microbe of varicella may, under certain as yet unknown conditions, give rise to a localised eruption resembling 
Herpes zoster, and that this again may further give rise to a varicellalike eruption. He adds that in May, 1912, together with an epidemic of varicella at Budapest, there was evidently a kind of epidemic of Herpes zoster, for during that period, in his hospital and private practice, he observed more cases of Herpes zoster than he had ever observed before in the same time.

Hepworth (27) records a case of Herpes zoster in a mother being followed by varicella in her son after sixteen days interval. Howard Distin (29) tells of a severe attack of Herpes zoster in a father, followed, after twenty-two days, by varicella in his daughter, aged 5 years, though she had apparently not been exposed to any known source of infection. W. P. Le Feuvre (23) gives similar examples observed by himself and by various other medical writers. Instances of varicella being followed by cases of Herpes zoster have likewise been recorded (23 to 26). References to many publications bearing on this alleged connection between Herpes zoster and varicella are given in the References and Notes at the end of this paper (Nos. 21 to 29$)$.

That real Herpes zostel is due to the same (unknown) cause or morbid agent as varicella appears to me extremely improbable. In the first place, if that were so, one would expect, during epidemics of varicella, to meet fairly frequently with children suffering from typical Herpes zoster, and not merely presenting local zoster-like groupings of varicella vesicles, such as has been alluded to by von Bokay (21), Heim (22), etc. Furthermore, during epidemics of varicella, one would expect to find Herpes zoster in children at the same time as, or preceding, an eruption of varicella, but one does not do so. Since typical eruptions of Herpes zoster do occur in children, one cannot (in terms of the theory in question) explain away the difficulty by supposing that children are not liable to that "modified form of varicella" which (according to the theory in question) manifests itself in the guise of Herpes zoster. In the second place, the eruption of Herpes zoster in my above-described leukæmia case (A. H.) seemed obviously to have been excited by the arsenical treatment employed, and though the Herpes zoster was associated with a slight generalised eruption of varicella-like spots, it would be a very far-fetched explanation to suppose that a varicella-infection was present and played any part in the causation of either eruption. So 
also in a boy, Roger S-, aged 8 years, to whose case I have alluded elsewhere (36), an eruption of typical Herpes zoster occurred on the right side of the chest, apparently as a result of arsenical treatment for Hodgkin's disease, and this Herpes zoster was accompanied by a generalised vesicular eruption on the trunk. [Such cases remind one, by the way, that Dermatitis herpetiformis has been reported to have followed the use of arsenic.]

It seems to me, however, that cases (see further on) of Herpes zoster may really be of an [as yet unknown] microbic origin, and this would explain the occasional almost epidemic-like frequency of the disease [Paul Heim (22), Kaposi (30), and other writers (31 to 33) ], and the examples of apparent contagion of the disease from one patient to another, for instance, the examples collected by Solon Veras (34), the observation of J. Galippe (35), etc. The ordinary sporadic cases of Herpes zoster might then be compared to the ordinary sporadic cases of certain infectious diseases of the nervous system, namely, acute anterior poliomyelitis or polio-encephalomyelitis (the "Heine-Medin disease") and cerebro-spinal meningitis.

If we assume, according to the writings of Head and Campbell (37), von Bärensprung (38), Boeck (39), Sattler (40), Magnus (41), Scheel (42), de Besche (43), André-Thomas and Henyer (44), Anton Sunde (45), and others, that typical Herpes zoster is due to an inflammatory or leukæmic ( $c f$. reference 19) or other change in the posterior root ganglia of spinal nerves, or in the ganglia connected with sensory cranial nerves, it is tempting to suppose that, when the herpetic eruption is accompanied by much local disturbance of sensation [especially by pain or anæsthesia], the inflammation has spread or "overflowed" along the sensory roots into the gray substance ( $c f$. reference 46) of the posterior horns ("poliomyelitis posterior"), or into the corresponding gray substance of the mesencephalon. Similarly, when the Herpes zoster is accompanied by local muscular paralysis and muscular atrophy, one might suspect that the inflammation has further spread or "overflowed" so as to involve the gray matter of the anterior horns, that is to say, the motor origins of spinal nerves ("poliomyelitis anterior") or the analogous roots of motor cranial nerves. (On these questions compare references 53 to 58 and 40 and 41, especially the notes given in my former paper, reference 53.) It would be quite conceivable that both the exact 
initial position (focus) and initial extent of the inflammatory or other lesion might vary much in different cases, and such a supposition would serve to explain the supposed occurrence of cases of Herpes zoster sine herpete, the attack of Herpes zoster being represented, not by an herpetic eruption, but by neuralgic pain, and possibly by some kind of paralytic or paretic nervous disturbance.

In regard to the further question of whether Herpes zoster may be due to the lately discovered microbic cause of acute anterior poliomyelitis ("Heine-Medin disease"), it is interesting to note that F. E. Batten (47) has seen a vesicular rash in the latter disease resembling diffuse herpes. He writes that the occurrence of herpes in relation to poliomyelitis is well recognised, but he adds: "It is curious how seldom a true herpes is seen in a case of poliomyelitis." (Of. reference 48. )

If Herpes zoster be really due to the same microbic cause as acute anterior poliomyelitis, how can one explain the now acknowledged (and in my limited experience not exceedingly rare) effect of arsenic in inducing an attack of Herpes zoster ( $c f$. references 49 to 51 , and 36). [In regard to the possibility of Herpes zoster resulting from carbon-monoxide poisoning, $c f$. references 40 and 52.] I have above alluded to two cases (the first case of this paper and case No. 2 in reference 36) in which arsenical medication induced not only an attack of Herpes zoster, but likewise a generalised varicella-like or vesicular eruption. An attack of generalised Herpes zoster has likewise been recorded by Fischl (19) in a patient suffering from lymphatic lenkæmia, but, unfortunately, it is not stated whether the patient was under arsenical treatment when the Herpes zoster broke out.

It is, of course, permissible to entertain the idea that a poweríul drug like arsenic may, in the case of some individuals, predispose to an infectious disease (Herpes zoster?). This I have myself ventured to suggest in regard to pneumonia, because I have observed the occurrence of a kind of pneumonia in various patients whilst under treatment with arsenic (36). Nielsen (49) thinks that there can be no doubt as to the fact that arsenic predisposes to Herpes zosterbut he says that the Herpes zoster from arsenic seems to be of the ordinary type-and that no fresh attack occurs if the arsenical medication is continued. 
The Ophthalmoplegic Complications and Frontal Anæsthesia.

In a recent paper on a case of "Herpes Zoster with Paralysis of Arm" (53) I gave references to various cases of Herpes zoster associated with muscular paresis, muscular atrophy, and unusual sensory disorders, including many cephalic cases in which ophthalmic, otic, facial, or occipito-cervical Herpes zoster was accompanied by oculomotor or facial paralysis or paresis, sometimes by paralytic mydriasis, and sometimes by disorders of the special senses of smelling, hearing, and tasting. In that paper, however, I unfortunately omitted to refer to the striking cases of H. Sattler (40), Magnus (41), and A. Jaehne (54). The numerous references to the literature given by Wilbrand and Saenger (55) should specially be consulted, as well as the writings of J. R. Hunt (56) and Norman Sharpe (57), in connection with the second case of my present paper. This case is remarkable not only for the severity of the actual herpetic eruption (the Zoster ophthalmicus seu frontalis), but for its being followed by frontal anæsthesia and by both external and internal ophthalmoplegic symptoms-namely, paresis of the superior rectus muscle and paralytic dilatation of the pupil. In regard to the dilatation of the pupil, we may mention that C. Achard and J. Castaigne (58), in an article on Cephalic Zona ("Herpes Zoster of the Cephalic Extremity"), described a case in which permanent paralytic dilatation of the left pupil followed an attack of left-sided - ophthalmic Herpes zoster, and referred likewise to two other cases in which (permanent or chronic) paralytic mydriasis of one pupil followed ophthalmic Herpes zoster of the same side.

The changes which have been found in cephalic cases of Herpes zoster confirm the work of Head and Campbell (37). Thus AndréThomas and Henyer (44), in a case of ophthalmic Herpes zoster, found changes in the Gasserian ganglion. In a patient who died three days after an eruption of ophthalmic (frontal) Herpes zoster, Sunde (4.5) found recent, partly hæmorrhagic, partly sero-purulent, inflammation in the Gasserian ganglion of the same side, and was able to demonstrate the local presence of many gram-positive cocci. In Sattler's case (40) and in Boeck's case (39) inflammatory changes were found in the Gasserian ganglion, and in Fischl's case (19) leukæmic infiltration of the ganglion was present. In Herpes zoster 
of spinal distribution analogous changes in the spinal ganglia are recorded $(38,41,42,43)$.

\section{References to the Literature and Notes.}

(1) H. Tenneson.-Traité clinique de dermatologie, Paris, 1893, p. 116.

(2) CosombinI on Herpes zoster generalisatus (1893); quoted by Fischl (19), Fasal (10), and Beyer (9). F. Mracek's Handbuch der Hautkrankheiten (Vienna, 1902, vol. i, p. 692), in the article on Herpes by Blaschko, contains an illustration of Colombini's case.

(3) JeAn Molrnié.--“ Des vésicules aberrantes dans le zona," Thèse de Paris, 1895-6, No. 97.

(4) Haslund.-OOn Herpes zoster; with generalised eruption; quoted by Fischl (19), Fasal (10), and Beyer (9), from the 8th volume of the Nordiskt Med. Arkiv, 1897.

(5) E. JeAnselme and Leredde.--"Sur les vésicules aberrantes du zona," Bull. et Mém. Soc. Méd. des hôpitaux de Paris, 1898, 3 sér., vol. xv, p. 619.

(6) W. L. Frrench.- "Herpes Zoster with Aberrant Vesicles," Brit. Med. Journ., 1899, vol. i, p. 388. Man, over sixty year's of age, suffered from febrile malaise, intercostal Herpes zoster, and varicella-like vesicles scattered over various parts of the body.

(7) J. A. ARKwright.--"Two cases of Herpes Zoster with a generally distributed Eruption." St. Barth. Hosp. Journ., London, 1900, vol. vii, p. 172.

(8) Braschko.-Article on "Herpes," in Franz Mracek's Handbuch der Hautkrankheiten, Vienna, 1902, vol. i, pp. 677-722. Copious Bibliography.

(9) R. Bryer.- "Herpes zoster mit generalisierter Lokalisation," Arch, $f$. Derm. u. Syph., Vienna, 1906, vol. lxxviii, p. 233; cf. the same writer's Inaug. Dissert., Griefswald, 1906.

(10) Hugo Fasal.--"Herpes zoster generalisatus," Arch. f. Derm. u. Syph., Vienna, 1909, vol. xev, p. 27.

(11) J. F. Schamberg.-"Generalised Herpes," Journ. Amer. Med. Assoc.. 1910, vol. liv, p. 532.

(12) G. NoBL (of Vienna)._-"Zur Kenntnis des Herpes zoster generalisatus," Wiener klin. Wochenschrift, 1911, Jahrgang xxiv, p. 14.

(13) FrIEDRICH SteUER.-- "Ein seltener Fall von Herpes zoster gangrænosus generalisatus," Wiener med. Wochenschr., 1911, lxi, column 1167. A woman, aged 76 years.

(14) MrNet and LechercQ.- “Du zona avec éruption généralisée," La Clinique, Paris, 1911, Année vi, p. 101. Twenty-five cases collected. Reference also to work of Gaucher and Girard.

(15) F. J. Coleman, "Shingles and Chickenpox," Guy's Hospital Gazette, London, 1913, vol. xxvii, p. 184. A man, over seventy years of age, developed an eruption of Herpes zoster, and, about two days later, an eruption resembling typical varicella.

(16) E. Jeanselme and A. Touraine, "Zona suivi d'un éruption généralisée des vésicules aberrantes," Soc. Franę. de derm. et de syph., Puris, Meeting of July 2nd, 1914. 
(17) A. Твчв (of Prague).- “ Herpes zoster generalisatus," Dermat. Wochenschrijt, Leipzig, 1914, vol. lix. p. 983 . Man, aged 60 years.

(18) G. Pernet.- "Generalised Herpes Zoster," Brit. Journ. Derm., London, 1914, vol. xxvi, p. 399.

(19) F. FrschL- - Herpes zoster generalisatus bei Lucæmia lymphatica," Arch. f. Derm. u. Syph., Vienna, 1913, vol. cxviii, p. 553. No mention is made in regard to whether arsenic was being used in the treatment at the time when the Herpes zoster broke out. Leukæmic infiltration of the Gasserian ganglion was found at the post-mortem examination. Many references to the literature of Herpes zoster generalisatus are given.

(20) —_ In this connection it is perhaps worth alluding to the occurrence of a generalised bullous eruption on giving antipyrin to a patient with Herpes zoster. See Frank Deas, "Bullous eruption due to Antipyrin, occurring in a patient suffering from Herpes zoster," Brit. Journ. Derm., London, 1899, vol. xi, p. 194. A man, aged 34 years. The generalised eruption reached its height about five hours after taking the first dose of the medicine [which was given for pain]. Disappearance of the eruption was rapid.

(21) JohanN von BoKaY.- "Ueber den ätiologischen Zusammenhang der Varizellen mit gewissen Fällen von Herpes Zoster," Wiener klin. Wochenschr., 1909, vol. xxii, p. 1323; also Compte-rendu du XVIe Congrès international de médecine, Budapest (1909), Section X (Pédiatrie), p. 480.

(22) Paur Heim.- “ Herpes zoster und Varicellen," Berliner klin. Wochenschr., 1912, vol. xlix, p. 2349.

(23) W. P. LE Feuvre.- "Herpes zoster and Varicella," Medical Journal of South Africa, Johannesburg, 1914, vol. ix, p. 177. Amongst the twenty-one instances given by the author of Herpes zoster in one patient apparently giving rise to attacks of varicella in others are two observations by himself in South Africa, and many observations recorded in the Brit. Med. Journ. and the Guy's Hospital Gazette. The author likewise quotes four examples of cases of varicella being followed by Herpes zoster, and refers to various instances of a varicellalike eruption and true Herpes zoster occurring in the same patient more or less simultaneously with each other.

(24) Arkman (of Guernsey), quoted by Le Feuvre, Medical Journal of South Africa, Johannesburg, 1914, vol. ix, p. 178, Observation 22. A child returned to school with the remains of a varicella eruption on it. Seven days later the schoolmistress, aged 30 years, developed right thoracic Herpes zoster. She had never had varicella. Eleven days later her sister, aged 25 years, and two children attending the school, developed varicella.

(25) (Anonymous).--"Shingles and Chicken-pox," Guy's Hospital Gazette, London, 1913, vol. xxvii, p. 219. A boy, aged 13 years, developed Herpes zoster two and a half weeks after exposure to varicella infection.

(26) E. A. Dando.-" Herpes and Varicella," Brit. Med. Journ., London, 1913, vol. ii, p. 1340. A patient developed Herpes zoster four weeks after the patient's son was suffering from varicella. A lady developed Herpes zoster five weeks after her daughter was suffering from varicella.

(27) J. HePworTh.—“ "Herpes and Varicella,” Brit. Med. Journ., 1914, vol. ii, p. 629. On August 24th a mother had Herpes zoster, and on September 9th her son developed a varicella eruption. 
(28) JoHN ORR._"Herpes and Varicella," Brit. Med. Journ., 1913, vol. ii, p. 1048.

(1) A man, aged 50 years, developed severe herpes of the scalp. His daughter developed varicella two weeks later.

(2) A man, aged 45 years, developed typical thoracic Herpes zoster, and three days later a varicella-like eruption.

(29) Howard Distrn.-_" Herpes and Varicella," Brit. Med.Journ., 1915, vol. i, p. 633.

(30) M. Kaposi.--“Bemerkungen ïber die jüngste Zoster-Epidemie," Verhandl. d. deut. dermat. Gesellsch., Vienna, 1889, vol. i, p. 57. Kaposi observed forty cases of Herpes zoster during twelve months, 1888-1889.

(31) Henry Taylor.- "An Epidemic of Herpes Zoster," Brit. Med. Journ., London, 1889, vol. ii, p. 13. Taylor saw four cases of Herpes zoster in one week at Guildford, and a firm of practitioners in the same town saw nine or ten cases. in the course of two months about that time.

(32) EмrL Wers.- “Ueber epidemischen Zoster," Arch. f. Derm. u. Syph., Vienna, 1890 , vol. xxii, pp. 609-629. On p. 622 the author says that several cases of Erythema multiforme were observed during the period of the epidemic of Herpes zoster.

(33) Breunr.-- "Das epidemische Auftreten der verschiedenen Herpesformen," Inaug. Dissertation, Breslan, 1891. Quoted by F. Fischl (reference 19).

(34) Solon Veras.-_" Herpes Zoster by Contagion," Brit. Journ. of Children's. Diseases, London, 1912, vol. ix, p. 360. Refers also to previous literature of the subject.

(35) J. Galippe._-" Un cas de zona cervical," Bull. Soc. de Pédiatrie de Paris, 1913, vol. xv, p. 200. Herpes zoster in two boys, living in the same house, with an interval of four or five days.

(36) F. PARKes Weber.--" The Occurrence of Acute Pneumonia during Treatment with Arsenic," Brit. Med. Journ., 1913, vol. i, p. 337 (case No. ii).

(37) H. Head and A. W. Campbel..-." The Pathology of Herpes Zoster and its bearing on Sensory Localisation," Brain, London, 1900, vol. xxiii, p. 353.

Case 18 (p. 501). A man, aged 31 years. Herpes zoster of the right side of the face (infra-maxillary division of the fifth cranial nerve). Death from general paralysis thirty days after the eruption. Post-mortem, the right Gasserian ganglion showed in its corresponding portion a focal destructive lesion.

Case 19 (p. 509). A man, aged 43 years. Right frontal Herpes zoster (ophthalmic division of the fifth cranial nerve). Death from general paralysis 190 days after the eruption. Post-mortem, there was a focus of disease in the part of the right Gasserian ganglion corresponding to the first division of the fifth nerve. The authors refer likewise to previous literature on the subject.

(38) F. G. F. von Bärensprung.-- "Die Gürtelkrankheit," Annalen des Charité-Krankenhauses zu Beriin, 1861, ix, part 2, p. 40;1862, x, part 1, p. 37 ; 1863, xi, part 2, p. 96. It is in the third part (1863) of von Bärensprung's elaborate series of articles on Herpes zoster that he describes a case of thoracic Herpes zoster in a boy, aged $1 \frac{1}{2}$ years, who died of tuberculosis six weeks after the commencement of the eruption. The necropsy showed inflammation of the corresponding spinal ganglia of the affected side. 
(39) C. BoEck, of Christiania (quoted by A. Sunde, reference 45), in 1878, found purulent inflammation of the Gasserian ganglion in a case of facial Herpes zoeter.

(40) H. Satrler.-("Verein deut. Aerzte in Prag," January 25th, 1889), Wiener med. Wochenschr., 1889, vol. xxxix, column 328. Herpes zoster ophthal. micus in a man, aged 85 years, after carbon-monoxide poisoning. Death occurred fourteen days after the eruption. Severe inflammatory changes were found in the Gasserian ganglion of the affected side.

(41) V. Magnus.-Norsk Mag. for Laegevid., 1902, p. 517; 1903, p. 877; 1906, p. 1429 ; quoted by A. Sunde (reference 45). A case of Herpes zoster with motor symptoms. Necropsy three weeks after the herpes eruption. He found Grampositive diplococei in the anterior horns of gray matter, but none in the affected spinal ganglia, which only showed ordinary inflammatory changes.

(42) O. ScheEL (1904), quoted by A. Sunde (reference 45). Inflammation of spinal ganglia in cases of Herpes zoster (death some weeks after the Herpes zoster).

(43) A. DE Besche (1910), quoted by A. Sunde (reference 45). Inflammation of spinal ganglia in cases of Herpes zoster (death some weeks after the Herpes zoster).

(44) ANDre-Thomas and Henyer.- "Anatomie pathologique d'un cas de zona ophtalmique," Société de Neurologie, Paris, Meeting of February 29th, 1912. (Revue Neurologique, Paris, 1912, vol. xxiii, p. 381.) The authors found changes in the Gasserian ganglion, confirming the theory of Head and Camphell.

(45) Anton Sunde (of Christiania).- " Herpes zoster frontalis mit Bakterienbefund im Ganglion Gasseri," Deut. med. Wochenschr., 1913, Jahrgang xxxix, p. 849.

(46) - In this connection it is interesting to note that Herpes zoster seems to be of rare occurrence in cases of Tabes dorsalis and syringomyelia. $C f$. A. Westphal, "Ein Fall von Tabes dorsalis mit Herpes zoster," Charité-Annalen, Berlin, 1897, Jahrgang xxii, p. 655. Westphal refers to reports by von Leyden, Erb, and Charcot, regarding the occurrence of Herpes zoster in patients with Tabes dorsalis.

(47) F. E. Batten.-Article on "Polio-encephalo-myelitis," in Garrod, Batten, and Thursfield's Diseases of Children, London, 1913, p. 767.

(48) - In this connection it should be noted that Herpes zoster may appear in, and is one of the more common cutaneous manifestations of, epidemic cerebrospinal meningitis. In tuberculous meningitis it does also, but very rarely, occur, See W. Evans, “Meningitic Herpes," Brit. Journ. Derm., London, 1900, vol. xii. p. 83. See also P. Durand, regarding the presence of the meningococcus in the herpetic vesicles in cerebro-spinal meningitis-communication to a medical society of Lyons, Presse Médicale, Paris, January 3rd, 1914, p. 11.

(49) L. NiblseN.- - Ueber das Auftreten von Herpes zoster während Arsenikbehandlung," Monatsheft für pvakt. Dermatologie, Hamburg, 1890, vol. xi, p. 302.

(50) BER thold Stein.- "Ueber den Herpes zoster arsenicalis," Inaug. Dissert. Heidelberg, 1901.

(51) AdolF Schmrdt.- "Herpetische Eruptionen als Vorstadium eines Hautcarcinoms neben Herpes zoster,' Arch.f. Derm. u. Syph., Vienna, 1904, vol. lxx, p. 321. The case was perhaps one of Herpes zoster occurring in a patient under arsenical treatment. 
(52) T. E. Leudet-B́tudes de Pathologie et de Clinique Médicales, Paris, 1891, vol. ii, p. 564: “Le zona peut-être l'effet d'une intoxication, comme celle par l'oxyde de carbone." Cf. Leudet's original paper: "Recherches sur les troubles des nerfs périphériques . . . consécutifs à l'asphyxie par la vapeur de charbon," Arech. Gén. de méd, Paris, 1865, vie Sér., vol. v, p. 513. Ivor J. Davies, in his account of the "Carbon Monoxide Poisoning in the Senghenydd Explosion" (Brit. Med. Journ., 1914, vol. ii, p. 57), mentions outaneous erythematous lesions as occurring in nine of the cases. In one case cedema, vesicles and bullæ were associated with the erythema ( $c f$. also reference 39 in the present. paper).

(53) F. Parkes Weber.- " Herpes Zoster with Paralysis of Arm," Brit. Journ. Derm., London, 1915, vol. xxvii, p. 408. This paper gives references to many records of Herpes zoster associated with paralyses and, in some instances, muscular wasting, as well as to many cases associated with unusual sensory disturbances, especially of the special senses of hearing, smelling and tasting. In the cases associated with paralysis, the paralysed parts generally correspond fairly well to the distribution of the Herpes zoster, but in exceptional instances the paralysis is located at a distance from the site of the herpetic eruption. Thus Mr. G. J. Jenkins kindly tells me of a recent case (a middle-aged man) seen by him, in which thoracic Herpes zoster (lower thorax) was associated with paralysis of the vocal cord on the opposite side; gradual recovery took place, though slight paresis of the vocal cord still manifests itself occasionally.

(54) Arthur Jaehne.- "Zur klinik des Herpes zoster oticus," Archiv für Ohrenheilkunde, Leipzig, 1914, vol, xciii, p. 178. The patient was a young man, aged 21 years, who fell ill with fever, lassitude, and jaundice. A few days later an eruption of Herpes zoster of the pinna and external auditory meatus of the right side showed itself. Three days later facial paralysis occurred and was accompanied by severe auditory disturbance, and followed by deafness. There was likewise loss of taste in the right half of the tongue. The facial paralysis was noted to be rather less after half a year, but the auditory and gustatory symptoms persisted. Jaehne gives numerous references to the literature of Herpes zoster oticus.

(55) H. Wilbrand and A. Saenger.-Die Neurologie des Auges, Wiesbaden, 1901, vol. ii. See pp. 188-206 for discussion on the nature and ætiology of Herpes zoster, with abundant references to literature of the subject. See pp. 176-183, in regard to the complications, especially the paralytic nervous complications, of Herpes zoster ophthalmicus.

(56) J. R. HunT.- "The Paralytic Complications of Herpes zoster of the Cephalic Extremity," Journ. Amer. Med. Assoc., 1909, vol. liii, p. 1456. References to many of Hunt's other writings on the subject are given in F. P. Weber's article in the Brit. Journ. Derm., 1915, vol. xxvii, p. 408 (reference 53).

(57) Norman Sharpe.- "Herpes Zoster of the Cephalic Extremity," Amer. Journ. Med. Sci., Philadelphia, 1915, vol. exlix, p. 725.

(58) C. Achard and J. Castaigne, "Zona céphalique," Gazette hebd.de Méd., Paris, 1897, Nouv. Sér., vol. ii, p. 1177. 